\title{
Evaluation of Secondary Malignancy Risk due to the Whole Body Computerized Tomography Simulation in Radiotherapy Facilities
}

\author{
Fatih BILTEKIN, Demet YILDIZ, Gokhan OZYIGIT \\ Hacettepe University Faculty of Medicine, Department of Radiation Oncology, Ankara, TURKEY
}

\begin{abstract}
Nowadays, the use of computed tomography (CT) simulation is getting widespread with the use of new treatment modalities like three dimensional conformal radiotherapy (3D-CRT), intensity modulated radiotherapy (IMRT), adaptive radiotherapy (ART) and stereotactic radiosurgery (SRS) in radiotherapy facilities. The main purpose of these new treatment modalities are to increase the survival and increase the quality of life by reducing the side effects. However, radiation induced secondary malignancy risk is getting important after radiotherapy with the increase in survival. Especially, CT scanning was performed from head to sacral region for 3DCRT craniospinal treatments techniques in children or young patients and several precautions should be taken to reduce the radiation dose due to the CT simulation. In this study, we measured organ equivalent dose in Alderson Rando phantom and we estimate radiation-induced cancer risk due to $\mathrm{CT}$ scanning for different conditions. According to our measurement, secondary malignancy risk was found to be between $0.10 \%-0.22 \%$ for different conditions in craniospinal CT simulation.
\end{abstract}

Keywords: Computerized tomography, Simulation, Radiation, Secondary malignancy risk

\section{ÖZET}

Radyoterapi Ünitelerinde Bilgisayarlı Tomografi Simülasyonuna Bağlı İkincil Kanser Riski Değerlendirmesi

Günümüzde radyoterapi uygulamalarında üç boyutlu konformal radyoterapi (3B KRT), yoğunluk ayarlı radyoterapi (YART), adaptif radyoterapi (ART) ve stereotaktik radyocerrahi (SRC) gibi yeni tedavi modaliteleri ile birlikte bilgisayarlı tomografi (BT) simülasyonunun kullanımı da yaygın olarak artmaktadır. Artan sağkalım süresi ile birlikte de radyasyondan kaynaklı ikincil kanser riski önem kazanmaktadır. Özellikle de pediatrik hastalarda BT simülasyonundan kaynaklı dozu minimize etmek amacı ile çeşitli önlemlerin alınması gerekmektedir. Bizim çalışmamızda ise üç boyutlu kraniyospinal radyoterapi uygulanan pediatrik olgularda BT simülasyonundan kaynak॥ çevre organların aldığı doz değerleri ve yaşam süresi boyunca düşük doz radyasyondan kaynaklı ikincil kanser riskinin değerlendirilmesi amacı ile Alderson Rando fantomda ölçümler alındı. Ölçümler sonucunda farklı ölçüm koşullarında (tüp voltajı, kesit kalınlı̆̆ı gibi) kraniospinal radyoterapi uygulamaları için gerçekleştirilen BT simülasyonundan kaynaklı ikincil kanser riski 0.10\% - 0.22\% değerleri arasında bulundu.

Anahtar Kelimeler: Bilgisayarlı tomografi, Simülasyon, Radyasyon, İkincil kanser riski 


\section{INTRODUCTION}

Since the introduction of computed tomography (CT) in 1970s, the use of CT in diagnostic and other therapeutic implication has increased and getting widespread rapidly. ${ }^{1}$ In 2007, It is estimated that approximately 72 million CT scan were performed in the USA and almost 4 million of these scans is performed in person who is younger than 18 years old. ${ }^{2}$ However, it is a known fact that ionizing radiation can break the molecular bonds of DNA and cause the formation of a cancer cell. ${ }^{3}$ The most important risk factors affecting the secondary malignancy risk due to the $\mathrm{CT}$ scanning can be defined as age of person and the amount of exposured dose which is related with tube voltage, scanning thickness, location and size of the scanned region. Therefore, ALARA principle. ${ }^{4}$ should be taken into consideration in every implication, especially for children, to reduce the cancer risk due to the ionizing radiation. In this study, we evaluate the secondary malignancy risk due to the craniospinal CT simulation for radiotherapy treatment planning.

\section{MATERIALS AND METHODS}

In this study, CT scanning and measurements were performed in $\mathrm{GE}^{\mathrm{TM}} \mathrm{Hi}$-speed NX/I CT Simulator, commercially available from GE Medical System, Milwaukee Wisconsin, USA. In the measurements, Alderson Rando phantom and about 80 thermoluminescent detectors (TLDs), TLD 100H, were used. Firstly, Alderson Rando phantom was scanned in $2.5 \mathrm{~mm}$ thickness by setting tube voltage as $100 \mathrm{kVp}$. Then, CT images were transferred to the treatment planning system. By using these images all of the organs and structures cited in "The International Commission on Radiological Protection" (ICRP) 103 publication ${ }^{4}$ were defined on each image to evaluate the secondary malignancy risk. TLDs were placed to defined organs and structure on Rando Alderson phantom and measurements were performed. We divided measurements into two parts as shown in Figure 1.

Secondary Malignancy Risk for Different Tube Voltage and Slice Thickness in Helical CT Simulation

In the first part, Helical CT scanning was performed in $2.5 \mathrm{~mm}, 5.0 \mathrm{~mm}$ slice thickness and $80 \mathrm{kVp}$, $100 \mathrm{kVp}, 120 \mathrm{kVp}$ tube voltages. After performed

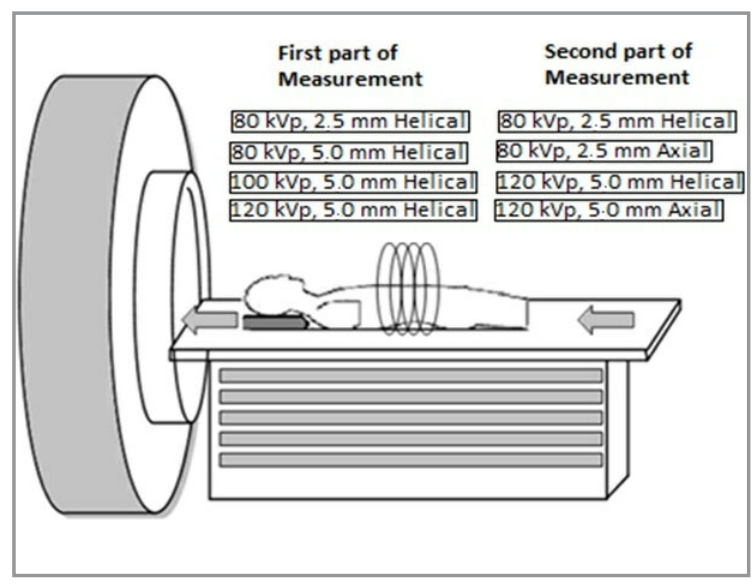

Figure 1. Measurements for different tube voltage and slice thickness in helical and axial CT simulation

these processes, TLDs were read and organ equivalent dose were calculated by using recommended tissue weighting factors in ICRP 103 publication. By using these data, we found effective dose and we calculated secondary malignancy risk per whole body CT scanning.

Comparison of Helical and Axial CT Simulation in terms of Secondary Malignancy Risk

In the second part, we measured organ equivalent dose and effective dose to compare secondary malignancy risk for helical and axial CT scanning applications in $80 \mathrm{kVp}$ and $120 \mathrm{kVp}$ tube voltages.

\section{RESULTS}

Secondary Malignancy Risk for Different Tube Voltage and Slice Thickness in Helical CT Simulation

Effective dose measured for different tube voltages and slice thickness were illustrated in Table 1. In the table, it is seen that effective dose increase with increasing tube voltage and decreasing slice thickness of scanning. According to ICRP 103 recommendation, lifetime cancer risk per $\mathrm{Sv}$ is reported as $5.0 \%$ and in this study secondary malignancy risk was found between $0.10 \%-0.17 \%$ for whole body CT scanning for defined conditions in the Table 1.

\section{Comparison of Helical and Axial CT Simulation in terms of Secondary Malignancy Risk}

According to our measurement results in axial CT 


\begin{tabular}{|c|c|c|c|c|}
\hline ORGAN & $\begin{array}{l}80 \mathrm{kVp} \\
2.5 \mathrm{~mm} \text { Helical } \\
\text { Effective Dose } \\
(\mathrm{mSv})\end{array}$ & $\begin{array}{l}80 \mathrm{kVp} \\
5.0 \mathrm{~mm} \text { Helical } \\
\text { Effective Dose } \\
(\mathrm{mSv})\end{array}$ & $\begin{array}{l}100 \mathrm{kVp} \\
5.0 \mathrm{~mm} \text { Helical } \\
\text { Effective Dose } \\
(\mathrm{mSv})\end{array}$ & $\begin{array}{l}120 \mathrm{kVp} \\
5.0 \mathrm{~mm} \text { Helical } \\
\text { Effective Dose } \\
(\mathrm{mSv})\end{array}$ \\
\hline Colon & 1.6 & 1.4 & 2.0 & 2.0 \\
\hline Small intestine & 1.6 & 1.1 & 2.1 & 2.1 \\
\hline Kidneys & 1.1 & 1.1 & 1.5 & 1.6 \\
\hline Liver & 0.5 & 0.5 & 0.7 & 0.7 \\
\hline Spleen & 1.2 & 1.1 & 1.0 & 1.7 \\
\hline Oesophagus & 0.4 & 0.4 & 0.6 & 0.7 \\
\hline Hearth & 1.6 & 1.6 & 2.6 & 3.4 \\
\hline Lung & 1.6 & 1.4 & 2.5 & 2.7 \\
\hline Breast & 1.7 & 1.8 & 2.8 & 3.2 \\
\hline Thyroid & 0.4 & 0.4 & 0.4 & 0.6 \\
\hline Spinal cord & 0.8 & 0.8 & 1.0 & 1.6 \\
\hline Oral mucosa & 0.5 & 0.6 & 0.7 & 1.1 \\
\hline Salivary glands & 00.6 & 0.06 & 0.07 & 0.11 \\
\hline Other tissues and organs ${ }^{\star}$ & 8.1 & 8.1 & 12.1 & 11.8 \\
\hline Total Effective Dose (mSv) & 21.16 & 20.36 & 30.07 & 33.31 \\
\hline Secondary Malignancy Risk & $0.10 \%$ & $0.11 \%$ & $0.15 \%$ & $0.17 \%$ \\
\hline
\end{tabular}

scanning secondary malignancy risk increase approximately $30 \%$ with respect to helical CT scanning (Table 2).

\section{DISCUSSION}

Organ equivalent dose and effective dose is getting increase with the increasing use of CT in medical facilities. Therefore, secondary malignancy risk cannot be underestimated due to the radiation dose delivered to patient during these applications. Furthermore, children are at greater risk than adults from a given dose of radiation since they are inherently more radiosensitive. Brenner et al. reported that estimated lifetime cancer risk from CT scanning in a 1 year-old are $0.18 \%$ (abdominal CT scan) and $0.07 \%$ (head CT scan). ${ }^{5}$ In another study, Furlow pointed out that 20 years old people who was exposed to ionizing radiation have a two times higher cancer risk than someone who was 40 years old. ${ }^{6}$ Despite all these data, it is estimated that $30 \%$ of computed tomography tests may be unnecessary. ${ }^{7}$ In addition to diagnostic use, CT simulation has been used widespreadly in radiotherapy facilities. Large body region, particularly in craniospinal patients, is scanned to use in radiotherapy treatment planning. However, this causes an increase in total body dose which cannot be negligible in children and young patients. According to our measurement, secondary malignancy risk was found between $0.10 \%-0.22 \%$ for different conditions in craniospinal CT simulation.

Several precautions should be taken to minimize lifetime cancer risk due to the CT scanning. The first one is choosing optimal CT thickness and tube voltage according to patient size. Second way is defining treatment region correctly and avoiding unnecessary CT scan out of the treatment region. The last and most important one is avoiding from unne- 


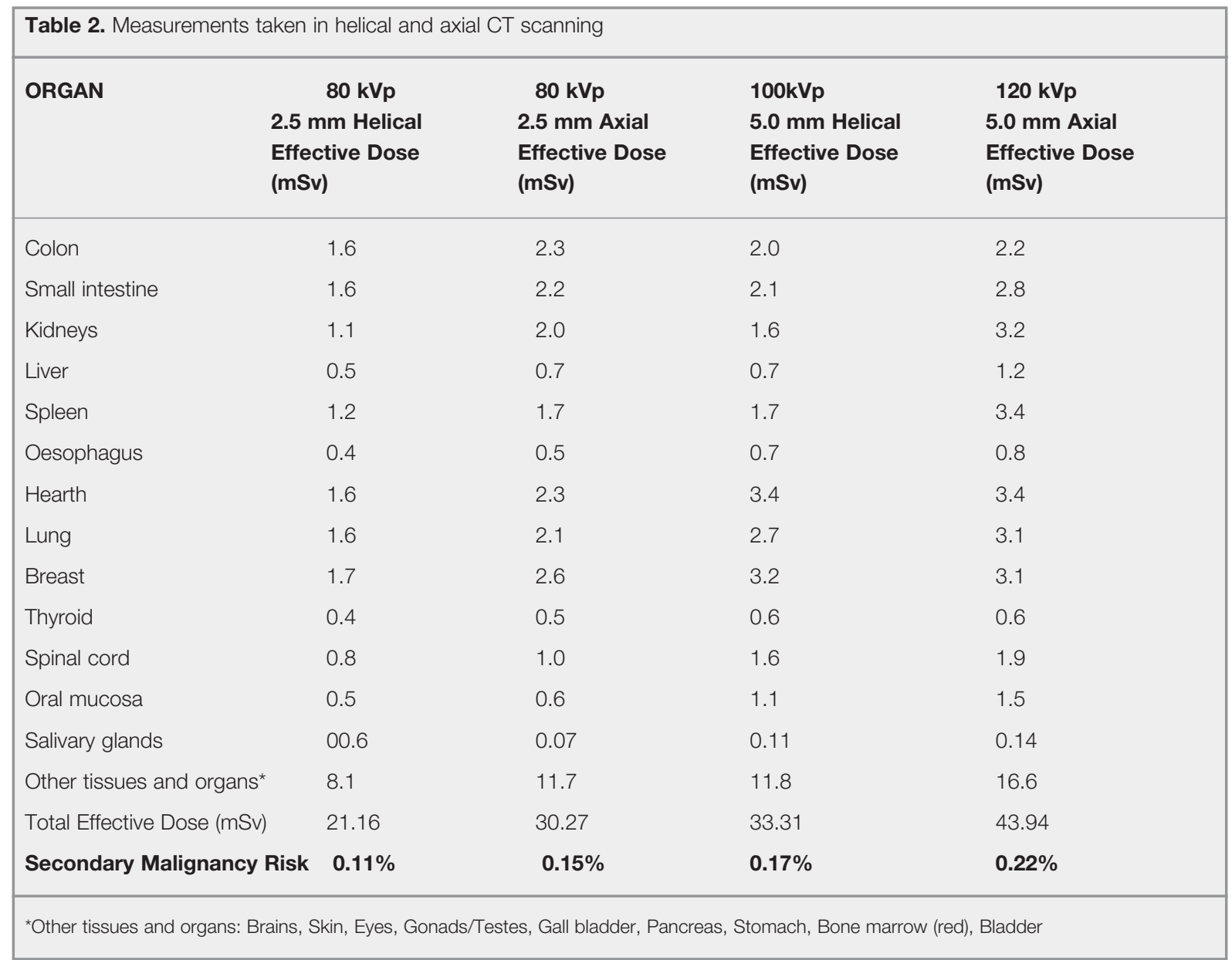

cessary CT scanning. In this manner, radiation-induced cancer risk due to the low X-ray dose during CT scanning can be minimized by paying attention to these precautions.

\section{Acknowledgements:}

This study was supported by TUBITAK Research Fund 109S488.

\section{REFERENCES}

1. Brenner DJ, Hall EJ. Computed tomography--an increasing source of radiation exposure. $\mathrm{N}$ Engl $\mathrm{J}$ Med 357: 2277-84, 2007

2. Berrington de González A, Mahesh M, Kim KP, et al. Projected cancer risks from computed tomographic scans performed in the United States in 2007. Arch Intern Med 169: 2071-7, 2009

3. Beyzadeoglu M, Ozyigit G, Ebruli C. Basic Radiation Oncology, Springer-Verlag Berlin Heidelberg, 2010: 83-84
4. International Commission on Radiological Protection (ICRP). The 2007 Recommendations of the International Commission on Radiological Protection, 2007

5. Brenner DJ, Elliston CD, et al. Estimated risk of radiation-induced fatal cancer from pediatric CT. AJR Am J Roentgenol 176:289-96, 2001

6. Furlow B. Radiation dose in computed tomography. Radiol Technol 81: 437-50, 2010

7. Davies HE, Wathen CG, Gleeson FV. The risks of radiation exposure related to diagnostic imaging and how to minimize them. BMJ 342: d947-d947, 2011

\section{Correspondence}

Dr. Gökhan ÖZYiĞiT

Hacettepe Üniversitesi Tıp Fakültesi

Radyasyon Onkolojisi Anabilim Dalı

Sihhiye, ANKARA / TURKEY

Tel: (+90.312) 3052900

Fax: (+90.312) 305

e-mail: gozyigit@hacettepe.edu.tr 